\title{
The Ability to Govern and Democratic Performance
}

\author{
Jaime Espejel-Mena \\ University Center UAEM Zumpango, Autonomous Mexico State University, Toluca, México \\ Email: jaimeespejel@hotmail.com
}

How to cite this paper: Espejel-Mena, J. (2021). The Ability to Govern and Democratic Performance. Open Journal of Political Science, 11, 54-72.

https://doi.org/10.4236/ojps.2021.111005

Received: November 5, 2020

Accepted: January 11, 2021

Published: January 14, 2021

Copyright $\odot 2021$ by author(s) and Scientific Research Publishing Inc. This work is licensed under the Creative Commons Attribution International License (CC BY 4.0).

http://creativecommons.org/licenses/by/4.0/

\begin{abstract}
The performance of weak democratic governments provides the conditions for business elites or political parties to isolate or focus public goods on society. The relationship between the State and society is nourished by positive freedoms and dignifies them, however, a government is required that amalgamates the objectives of the State, public services to the needs of the population, social capital, and limits negative freedoms. The objective of this article is to analyze the problems of governments in their national and local spheres, to consolidate their democracy through electoral or political channels and then to ensure a required capacity to satisfy the provision of services-formal arrangements-to demonstrate a efficiency, capacity and coherence to govern with mechanisms that demonstrate decisional capacity that consolidates democratic life.
\end{abstract}

\section{Keywords}

State, Government, Society, Democracy, Legitimacy

\section{Introduction}

In an influential book published in 2020, Darren Acemoglu and James Robinson highlight the freedom that is generated in the relationship between the State and society. The narrow corridor. States, societies and how to achieve freedom, highlights the need for the State and laws, but even more so for the checks and balances imposed by the presence of a strong society. Today, the necessary institutionalization of evaluation calls for innovation in some facets of human life, which is expanding considerably or is becoming a constant rule of governments, which are faced with the need to adapt their structures to new conditions, demands and opportunities (Franch Parella, 2020; Bielsa Callau, 2020).

This issue acquires particular importance due to the constant changes that 
occur in today's society and its effects on organizations whose own turbulence leads to complexity. This has become a significant category for analyzing the relationships between an organization and the outside world: the organization of the government and its institutions are also affected by it.

Change and conflict have become common in many nations, including non-Western ones. In the current period of history, characterized by a constant process of democratization, the government and its institutions constitute a constant and dominant factor in national and international society. As a consequence, government participation and bureaucratic structure have been a crucial factor in controlling this turbulence and a fundamental determinant of government legitimacy. This participation also means that institutions must readjust to changing conditions, demands and opportunities, which vary dramatically from one country to another and which depend on the prevailing social and political systems and the level of national development.

Governance as coherence and political flexibility requires several moments. It demands institutional legitimacy and political and administrative efficiency. The exercise of the domination of political power is subject to the citizens' assessment of their institutions, their members and their results. Institutional, political and administrative satisfaction or dissatisfaction can be transferred to the evaluation of democratic life.

In this document, we make the assumption that the norms, rules, products and values of government actions do not have a clear legal or institutional source, and their institutional legitimacy is at the expense of political and administrative efficiency, since rationality and legitimacy are not founded on instituting circumstances, but instituted and imposed by changing organizations.

It is concluded by panting that the presence of a strong State and clear laws is essential, however, freedom and legitimacy do not come from these, and its origin is found in the checks and balances raised by society. Freedom, legality and legitimacy require that there be a society that participates in politics, that is constituted in the balance of the power of the State.

\section{Systems and Institutions in Public Administration}

Freedom and legitimation are the result of the relationship between the State and society (Acemoglu \& Robinson, 2020). It has been reviewed by at least two different theoretical approaches, systems theory and institutionalism. The relationship between the institutions that the state creates from the bottom up and the legal traditions that are expressed in free and participatory societies create and recreate freedom and legitimacy. According to Acemoglu \& Robinson (2020), freedom is the ability to order actions and dispose of your person and belongings. While legitimacy is the result of the acceptance of checks and balances by a society involved in politics.

In systems theory, the administrative system, which functions within the political system, is represented by the conjunction of bureaucratic agencies, secre- 
taries, parastatal entities and other centralized or decentralized government agencies, as well as their internal and external processes. Like the political system, the administrative system is in turn made up of various subsystems. Kast \& Rosenzweig (1977) use the term administrative system when referring to these subsystems, that is, the combination of the administrative unit and all the elements and procedures that interact with the unit. The activity of any part of an organization affects the activity of any other. The theoretical scheme that I consider an organization as a system, is the input and output model, it states that the government nurtures its legitimacy of inputs or demands, and its internal conversion into results or responses. The systems model has also been used to study the totality of political-administrative structures and procedures. David Easton (2012) is the pioneer in developing a framework for a theory of the political system, while Gabriel Almond and Bingham Powell (1972) developed a schema for political systems, particularly considering comparative studies in politics.

In various functions of the conversion process, government plays a central role: its subsystems are included in these functions to varying degrees. Internal inputs are important aspects of the process. Exits are carried out through conversion processes: these can be bills submitted for consideration by Congress or Parliament, executive decisions, rules and regulations, government programs, mechanisms and regulations for the control and management of social forces for maintenance of the security and public order services. For these cases a distinction must be made between formal and real departures. The former include formal decisions, the latter the effects these decisions have on reality. The outputs of the government subsystems are similar to those mentioned previously, but they also include proposals and services to other parts of the structure: cabinet proposals, decisions of the State executive or decisions of specialists in government processes (Easton, 1996).

It has been suggested that the demands made by the environment-whether explicit or implicit-as well as the procedures and interactions with the government structure, can create tensions that give rise to a demand and to the modification of structures and processes. This also applies to the subsystems of the structure. The outputs that are directed towards the reorganization of structures and processes become a response-or laziness-of various parts or units of the governmental structure and of the individuals incorporated into the organization.

Two main factors, in the system-environment relationship, codetermine the effects of the environment on government organizational structures and processes: the degree of openness of the government structure and the type of environment. Regarding the first element, it allows us to observe to what extent the spontaneous or induced change of government structures and processes are caused or influenced by the environment. This is decisive to the extent that members or groups immersed in the governmental structure, look for and detect signs of the environment that are relevant to the governmental structure itself. When considering the aspects that open up in government organizations and 
institutions, an issue that has traditionally been considered a fundamental weakness of political bureaucracies is revealed, especially due to their lack of interest in the needs of the political community. This type of relationship between society and government causes significant inertia to characterize when government structures are closed or open.

Some factors that make explicit the openness of governments towards social demands are the following. First, it depends on how the upper echelons of the bureaucracy are made up, what values prevail within the political community, and how plural the political decision-making class is. Second, the regulatory framework for decision-making, the skills and competencies of those responsible for designing efficient policies, and a correlation between the demands of civil society and the organizational change of the administrative structure. Third, the relationship between political authorities and administrative structures, especially since the relationship is not always symmetrical since sometimes the same agent fulfills both roles (Morlino, 1985).

Regarding the second element, the type of environment drives organizational change by virtue of the fact that it is induced from outside the system. Under this logic, organizations that survive the pressures of the environment are due to the quality and quantity of their resources. In contrast, organizations whose autonomy from the system is relative are less susceptible to external conditions, as well as opportunities for change. This can also apply to government subsystems. If they are relatively independent, they may be less affected by external influences, which does not necessarily limit their ability to change. If the governmental structure, in a broad sense, tends to be static and conservative, the degree of autonomy of a subsystem can favorably affect its relative capacity for change (Rustow, 1992).

The degree of induced external change is also determined by the nature of the environment. Various efforts have been made to classify organizational environments (Mintzberg, 2002), in a particular way we highlight the importance of those media that contain common elements and are not mutually exclusive. So far, we can say that the explanation of political and administrative efficiency formulated by the systems approach was based on a causal and formal relationship. The exercise of the proper domination of political power requires more than facts, efficiency is also the result of feelings and wishes of citizens. In short, the need for a substantive strategy for planning and executing political and administrative efficiency within and outside the government structure is pertinent. Improvised and incoherent changes and reforms can solve urgent and temporary needs, but they represent vulnerable responses to the fundamental weakness of the system and disregard the systematic properties of the governmental structure.

From the perspective of the new institutionalism, the historical institutionalists were influenced by the structural-functionalists when they understood politics as a system of interacting parts, but they rejected the tendency to observe the social or cultural forms of individuals as the parameters that manipulate the sys- 
tem operation. They understand the institutional organization of politics as the main factor that outlines collective behavior and generates definitive responses. Thus, there is a struggle for an implicit structuralism in government institutions, instead of functionalism supported by old proposals that observe political results as responses to the needs of the system. This type of neo-institutionalists accepts the argument that the conflict between cliques, produced by the scarcity of resources, centers on politics; but at the same time, it seeks inquiries to distinguish the political results and the inequalities that the results indicate (Powell \& Dimaggio, 1991).

This school found such explanations in the way in which conflicts are exchanged between the structures of political and economic organizations, by privileging certain interests and neglecting others. These new institutionalists attach high significance to formal political institutions, as well as to the development of broader concepts of how and what institutions they transcend. Most of the neo-institutionalists of this current understand institutions as formal or informal procedures, routines, norms and practices inserted in the organizational structure of politics. For them, institutions oscillate between the rules of a constitutional order or the average operating processes of a bureaucracy and the agreements that predominate in the behavior between formal associations (Hall \& Taylor, 1999).

There are four characteristics that distinguish this school. On the one hand, they tend to conceptualize the relationships between institutions and individual behavior in broad segments; second, they emphasize the asymmetries of power related to the operation and development of institutions; third, they lean toward an institutional development perspective characterized by dependency; finally, they are concerned with integrating institutional analysis with the contribution of other factors that can be revealed in political results. Regarding the perception of how institutions impact the fulfillment of individuals, as a central issue in any neo-institutional analysis, two proposals are presented: the calculation approach and the cultural approach. Both show differences in how actors behave, what institutions do, and why institutions persist over time.

According to this approach, institutions affect, above all, behavior, since the actors give a greater or lesser degree of certainty to the organizations, since they provide relevant information for the fulfillment of mechanisms for the agreements and also for the organizations penalties. The central point refers to the fact that institutions impact individual action by modifying the expectations that an actor has about the courses of action that others adopt for this reason, strategic interaction plays an important role in the analysis (Peters, 2003). The cultural approach, on the other hand, emphasizes the degree to which behavior is not a completely strategic matter, but it is part of a more global and universal vision of the individual. This school, without denying that human behavior is rational or has a purpose, looks at how far individuals change established routines or behavior patterns to achieve their goals. The approach tends to view individuals as satisfiers, rather than utility maximizers, in addition to pointing out to 
what degree the choice of a course of action depends on the interpretation of a situation, rather than a pure instrumental calculation.

Historical neoinstitutionalists are eclectic in the sense that they accommodate other approaches in order to specify the relationship between institution and action. For this reason, it is explained that institutions are resistant to institutional redesign, since they structure their own choices about the reform that the individual intends to promote. A second characteristic of the analysis in historical institutionalism refers to the preponderant role granted to power and its relations; Hence, all neo-institutionalist studies have a central treatment on this issue, above all, in the way in which institutions distribute power among social groups. Therefore, instead of considering predetermined scenarios for recruiting individuals, historical institutionalists are prone to assume that there is a world in which organizations give incentives to groups for their access to the decision-making process (Powell \& Dimaggio, 1991).

This current, on the other hand, is related to a perspective of historical development based on the concept of social chance, in the sense that it ignores the principle that operative forces generate similar results in organizational sources. Rather, they favor the perspective that the effect of those forces will be measured by contextual signs of a specific, naturally institutional situation. For this reason, organizations are taken as relatively persistent elements of the historical panorama and as one of the central factors that lead to historical development through a set of incremental routes, in periods of continuity, but punctuated by critical junctures when an institutional change takes place. Historical institutionalists pay significant attention to the role of institutions in political life, seldom insisting that organizations are the only causal force in politics. They aim to center organizations on a causal chain that incorporates a relative role to other factors, especially in terms of political development and the diffusion of ideas. At the core, these institutionalists take for granted that the world is more complex than the world of preferences and institutions, often postulated by rational choice institutionalists.

The citizen, by rejecting the institutions that exercise power over him, is rejecting his public administration that provides services, however, the citizen, by evaluating the provision of public services better and better, does not necessarily validate their public institutions. The performance of a government must be increasing, this improvement of services is a necessary condition for citizens to value public institutions positively, but it is not enough, since the true origin of the governance problem is of a political and political nature, not administrative efficiency. This refers us to the consent of the domination exercised by political power over the citizen, through a democratic political process to elect the government and subsequently demonstrate a capacity to govern.

\section{Political Efficiency}

Change and transformation are inseparable from the nature of the individual. 
The political, social, economic and cultural contexts with which the classical public administration was born in the Welfare State are no longer the same. Today, political and administrative efficiency and effectiveness, as sources of generation and regeneration of the State, are key elements in the way of carrying out the new public management. Despite constant changes, public administration persists with other principles and other ways of operating, but the need for a source of legitimacy and its governing process remains intact (Arenilla, 2010).

At first, the structural elements of government organizations were relevant, political and administrative efficiency was based on legal efficiency, public administration largely fulfilled its functions of social linkage and articulation, through the attention of the old and new social problems with minimal taxes and strong social policy. Changes in the structure and power, as a result of the functions attributed to the public administration, were legalized or formalized. Procedures were established with the aim of regulating and formalizing legal structures and instruments, to protect citizens and institutions from violations or abuses of power (Blanco \& Gomà, 2002). At the time, the political and administrative efficiency of the Welfare State was not enough to be limited to the spheres of action and behavior that it explicitly included in the formal institutional framework. A good part of public administration, in fact, concerns activities that often escape the various traditional approaches of administrative or legal sciences. It began to be assumed that capacities and actions are usually present in every government to resolve countless conflicts of interest that arise within the sphere of the political system. The causes of the crisis of the old Welfare State gained consensus, to which the financial crises, the oil crisis and the harsh budget programs of the 1970s contributed (Arenilla, 2011).

\section{Administrative Efficiency}

Administrative efficiency, in the version of the new public management, has as a source of legitimacy public recognition, rather than formal adherence or the constitutional scheme. Citizen support for a State, to a large extent, is the result of efficient and effective performance, when inequality and poverty are reduced, the democratic State and citizens are strengthened through the provision of services, laws, actions and it is complemented when the public observes that the performance of decisions is fair, that is, when public management creates value (Barzelay, 2003). The current of the new public management, puts the center of attention of the administrative efficiency in the achievement of results or in the better management of public affairs. The new public management, the search for quality, governability or compliance with codes of ethics feed reflection on public institutions with the aim that they enjoy greater legitimacy and acceptance by citizens.

The basis of the new public management is the efficiency of results. The legitimacy is specified with the evaluation of public management. Citizen priorities determine government actions, compliance with these is measured periodically, 
the competitiveness shown by the public apparatus is necessary to achieve citizen satisfaction. The citizen-client binomial is the one that validates the government's actions. The public administration is the manager of the contradictions that occur within it. Measurement of results and citizen satisfaction are substituted for legal-rational efficiency (Baena, 2010).

Political efficiency is understood as the aptitude, competence or potential of a government to set guidelines that lead to objectives considered valid by a society at a given time. In turn, the administrative capacity, considered as a particular case or a logical derivation of the first; it could be viewed as the institutional and operational potential that enables the implementation of the socially accepted and legally established objectives in the political constitution of the State in question.

To a large extent the authority of any institution, as Max Weber (2019) has argued so persuasively, is ultimately based on the popular belief of legitimacy. Therefore, the considerable and persistent challenges to the legitimacy of government institutions should be viewed with concern, as they threaten to undermine government capacity. In this sense, the legitimation of a democratic state is based on its political constitution and the political process by which political power and its ruling class are renewed.

The distinctive quality of the modern state is that it depends on the administrative process as the main instrument for shaping national policy. However, conditions may arise that create and explain the establishment of agencies or organizations to compensate for institutional deficiencies in the formulation and administration of national policy itself. The fact that the management process acquires a certain autonomy generates the risk of depersonalizing the political responsibility that the rulers acquire, after a democratic political process.

Institutions, systems and structures develop their trajectory in the sphere of the powers of the State and the spheres of government. Those are elements that can be defined as the formal power structure. In turn, the political parties and interest groups that define the pluralist society gravitate over these jurisdictions. These elements form the layer of informal power that conditions the provision of inputs and the obtaining of public products. Institutions, systems and structures then appear to be governed by superstructures of pyramidal power, sometimes formal and precise and other times informal and diffuse. The intelligent agents of the organization manage the cells or subunits of public action; their decision-making is influenced, with greater or lesser notoriety, by the directives of the secretaries, ministers or directors of the systems; the subunits are influenced by the orientations of the parties to which they belong, the pressure of groups and public opinion, religious organizations or the military.

The separation of powers remains open to theoretical controversy as a consequence of constitutional practices (Günther \& Cancio, 2003). At first it represented a balance between political efficiency and administrative efficiency: public action was ultimately subject to the approval, interpellation or censure of the representatives of the people. However, since the emergence of political parties, the 
balance was threatened. In presidential regimes, the president tries to create an image of independence from his party rank, although this is sometimes not politically feasible. For their part, ministers and legislators do not disdain that line that keeps them intertwined with their party when making decisions (Linz, 1997).

In such circumstances, it makes no sense to speak of power through consensus versus power through administration; administers the political party or coalition in power and censors those who remained in the opposition. If the same executive party dominates the Congress, the latter does not control the former; if the political party that made up the Executive is a minority in Congress, it may prevent it from managing with ease. This is the everyday history of the so-called division of powers, in contemporary constitutionally governed countries. The fact that these countries are the least studied in the political science literature does not hide the reality that they are the most numerous on a world scale (Linz, 1996).

The political process is involved with the administrative process. It is difficult to conceive, even in socio-political systems with marked structural differentiation, the total separation of functions that the existence of a strictly instrumental public administration would imply. All administrative behavior carries with it some political implications, and the fact that pressure groups seeking power act in close proximity to the decision-making levels of the public administration cannot be ignored. Moreover, it can be affirmed that the struggles that are unleashed within the public administration have become a main form of political action.

In various Western nations, the thesis that the State administration is modern, being organized by Max Weber's rational-legal model, still persists. The detail of this appreciation is the correlation of a modern public administration with an industrialized and politically pluralistic society (Weber, 2019). However, the rapid economic transformation aimed at industrialization does not require as a condition the adjustment of administrative structures to the norms derived from the Neo-Weberian model. Politically, Samuel Huntington (2016) argues that an autocratic system has greater possibilities of promoting deep economic transformations in the short term than one based on political competition (Deutsch, 1998).

A constant practice in countries in the process of political change is the tendency of political elites to centralize the administrative process, using the administration as an instrument to exercise control over local governments. In effect, contemporary regimes-with instability in their political processes, as well as unstable in their economy-have had to promote socioeconomic transformations through tight control of the administrative process, that is, direct decision-making efficiency and its public value (Huntington, 2016). In general, for the structures of a government in transition, the value of the centralization of the political and administrative process is always greater than the autonomy and search for consolidation of their efficiency (Nolte, 1991). 
The thesis that considers the public function as a source of political will, both of the representative and the administrator, is classic. The argument for such an assertion lies in the multiple condition of the individual vis-à-vis politics and public administration, that is, as an integral part of the source of political efficiency or as part of administrative efficiency. When Vervigratia performs bureaucratic tasks, it fulfills part of an administrative process and when it exercises a right or fulfills an obligation of a political nature, it coincides or disagrees with the group in power, which it serves.

Ultimately, formal institutions appear as the affordable instrument with which modern states democratically legitimize their daily social work. Institutional legitimacy is an indispensable condition for institutional effectiveness by endowing them with an inherent capacity to impose obedience and respect. Legitimacy allows an institution to achieve its goals without the regular need to threaten the use of force and to create renewed episodes of public resentment. One assumption is that a State, especially one that is born from a violent change, revolution or political transition, consolidates its socio-historical legitimacy to the extent that it translates into realities the objectives that it includes in its ideological platform, and these are established as means to resolve the popular demands that gave rise to it. This set of objectives in turn implies the designation of instruments of action or agents of change of a political, economic, social and administrative nature, which must be oriented to the operational translation of the goals that constitute the nation's project; which is generally collected by the constitution or formal institutions of each country.

\section{Some Performance Findings on Government Stocks}

The actions that the government produces are not actions that are the product of linear, incremental, total or limited rationality; on the contrary, they are the result of a constant negotiation process between public and private actors, who exchange resources and information in order to influence their political and administrative results.

Administrative systems, bureaucratic apparatuses, public managers, the career civil service or the government, are state apparatuses that seek to create and recreate its legitimacy. Efficiency, legitimation, legality, functionality and administrative rationalization are some trends that will have to be achieved with the proper action of the State and its predominance in political activity. The legitimacy of the changes in the administrative structure of the State is granted by the rapid social changes that occur, and not in the legality that they serve.

The mutations of the community-State, the integration of economic blocs, the increase in economic inequality, cultural segregation, the multiculturalism of society, constitute realities that demand the revaluation of the State that we know. The paradigm of rational choice (Buchanan \& Tullock, 1993), the postulates of the theory of the minimal State (Nozick, 1990) and the new institutionalism (March \& Olsen, 1997) have the political pretension of revaluing the State in an 
uncertain world. The thesis of Georg Sorensen (2011) is that turbulent times are lived as a result of the conclusion of the Cold War and the entry into a contingent context in which the State is witness to unprecedented realities: terrorism, struggle of identities, globalization, regionalization, governance, social networks, policy networks, responsibility, transparency and accountability, good government, new sovereignty, withdrawal of the State, economic and political integration, post-national State, democratic governance, liberalization, democratization. In this context, the State administration is also adapting to new axes: 1) democratization of the administration; 2) main agent relationship; 3) network vision, 4) management and responsibility; and 5) implementation of public capacities (Uvalle, 2009).

The encounter between the stable and continuous that characterizes modernity, and the discontinuous and complex that frames postmodernity, have confronted their emblematic historical reality: the modern State. The encounter between order and chaos is contradictory for the State, there is no perfect order or perfect disorder, the product of the union between two or more components is the complexity that the State faces. Faced with these events, it is pertinent to continue asking ourselves: How to deal with the constant changes that occur in the sources of political and administrative legitimacy of the government today?

In this regard, Charles Tilly (2010: p. 20) states that "the quality of public policy in one regime or another depends significantly on the relationships between the basic trust networks of the people and the government strategies of the rulers". Trust-like trust networks-is inherent to the legitimacy of government actions or policies. Thus, public policies are the product of the consensus between rulers, government agents, governments, political actors and the regime.

Policies always underlie a claim to efficiency in solving problems. However, for policies to generate confidence in the public sphere, it is unavoidable for the rulers or elected authorities to be known; it is essential that government agents and political actors speak on behalf of the government; and a leading role for non-governmental entities is crucial. In this sense, in order to create a network of trust in the results of the State's work, the condition is that all the agents involved in the policies work collaboratively. Tilly (2010) himself, following Adam Smith, suggests that networks of trust in "commercial countries" work by kinship, however, networks based only on kinship as civilization advances, they weaken and give step to more complex relationships, such as politically active associations or the incorporation and career of network members in public administration. Participants in these networks obtain personal benefits and protection against possible eventualities, aids that they will not be able to acquire elsewhere. The assumptions of rational choice, game theory or economic neo-institutionalism are present in Charles Tilly's analyzes, since networks, on the one hand, are the result of individual calculations on costs and benefits, of the relationships between agents and principals or the decrease in transaction costs.

The review of the trust networks that Tilly proposes goes further: it allows us to distinguish between government actions-actions of government agents and 
social actions-actions of political actors. The former are actions of the government towards society, while the latter go from society to the government. Both actions, separately, cause suspicion or lack of trust. Society's trust networks, by polarizing, only express and amalgamate certain links, cause suspicion to the rest of society, and can form a collective action that forms a social movement.

The connections between public policy and trust networks vary. At one extreme, trust networks operate within the government because they are regular units that the government apparatus itself leads and determines. On the other hand, trust networks operate outside the government, out of the government's sight, without surveillance controls. These networks change their position to move towards or away from public policy, when the trusted network lives under the protection of an intermediary, relatively autonomous, it can move away from the tuning of the government, on the contrary when the trusted network connects with the government can help satisfy the demands made on the political authorities.

Charles Tilly (2010: p. 52), suggests the review of trust networks, from a form of combined structuralism, that is, structures not only understand and reproduce themselves, they are also the product of exchange interactions between individuals and their "... approach reverses the causal direction, treating attitudes not as causes, but as effects of social interaction." A clear example of this is that trust can influence democratization, as well as distrust in de-democratization. Political regimes and trust networks face common problems. They face organizational difficulties in their internal functioning, which are reflected in their preservation and in the relationship between one and the other. Both depend on structures that provide them with new resources for their continuity, that produce and reproduce their main activities.

According to the structure of the organizations, these can work at least under three schemes: 1) in an authoritarian way; 2) cooperatively and 3) through trusted networks. For Tilly in trust networks, long-term risk is valued differently and the conditions of human beings are recovered, that is, trust networks store, produce and capitalize on the experiences of the network. Individual or group participation in the construction of network infrastructure contributes to the creation and recreation of social capital. On the contrary, when public policy encourages distrust or when social processes determine human relationships and wrongdoing is privileged, social capital will be zero. "The long history that we have investigated suggests that, to the extent that high-capacity states that make special use of capital and commitment as incentives for participation, the contingent integration of trust networks into public policy will also persist" (Tilly, 2010: p. 255).

Contingent public policy, not legitimate to government actions, does not generate social capital, does not restore the relationship between trust-legitimacygovernment, does not promote trust networks, does not generate institutions, does not create instituting value. In the opinion of Claue Lefort (1990), political and administrative efficiency cannot be reduced to legal institutions or mechan- 
isms that legitimize decision-making by the majority or the minority in government. The idea and the democratic context of legitimacy presuppose and are legitimized in the face of words such as respect for individuality, representation, institutions, political parties, participation, human rights, tolerance or sovereignty. The idea suggests the assumption that democratic, transparent, legitimate or homogeneous institutions subordinate the individual to social cohesion. The search for political and administrative legitimacy, through the defense of national sovereignty, to maintain social harmony, a defense of individual rights and freedoms, remains inconclusive if it is not equivalent to the common interest, that is, to political freedom. For Lefort (2007), the essence of the political is revealed in individual freedom and political freedom, by the individual and the citizen, by civil and civic values. The integrality of the argument is the ultimate foundation of legitimacy in a modern democracy.

When human actions are constituted by experiences based on individual freedom and political freedom, a new adventure begins, a new way of feeling and knowing, certainties are nuanced, knowledge is put into question. The institutionality of society is questioned by a law, by a power or in a State. A new idea arises, a new experience, new principles that transcend customs, traditions, the heterogeneity that accompany the domination of the individual by law, by society, by the State, by all organizations that impose an instituted value. Legitimation in a modern democracy is constituted as a process without beginning or end, the indeterminacy of legitimacy, is far from any empirical fact, from any quantification of the satisfaction of demands or the percentage of compliance with certain obligations.

The determination of society, the society with history, the society with unique referents, the determination of empirical facts reduce democracy to totalitarianism. The indeterminacy of power exalts individual freedom and political freedom, preserves the questioning of any single explanation of legitimation: in modern democracy legitimation is born in each act, it cannot be reduced to political, administrative, economic, cultural, social, or otherwise. For Claude Lefort (2007), legitimation is a symbolic mutation, a space that no one can occupy once or forever. Legitimization is a circumstance that is inaugurated with modern democracy, in the early nineteenth century, democracy more than a form of government is a form of society. According to Lefort, the great challenge of democratic society is the dissolution of certainties, the collapse of the indicators that determine the man with good or bad behavior. Democracy leads the individual, encourages him, subjects him to the challenge of creating his own foundations that recognize his own institution: in this case democracy. The foundations of democracy present foundational features that make it indeterminable, uncertainty is inherent in all forms of democratic society. Democracy and its legitimacy have a symbolic order, a political order, which is made and remade by individuals.

No truth, no justification is immutable, since the origin of power will have to be thought about, because it no longer belongs to someone. Power belongs to 
democratic society; power potentially belongs to everyone and cannot be personified by any subject or group (Maestre, 1994). Power is an empty place, it is unoccupied by a single person, it is a symbolic place that only occupies and controls the vote. In the paradox of the argument, in the ultimate indeterminacy, in the dissolution of certainties, lies the foundation of power. On the contrary, when power takes shape, when the search for truth is replaced by truth, when the people are replaced by the prophet, when power becomes something particular at the service of a few, democracy is assumed as totalitarianism.

Accountability, transparency, legitimacy, legality, will have to be rethought in their civic value, in their character and foundational nature of the constitution of political rights as human rights, that is, not as actions or government policies, even more as inherent to the form of society, as parts of a social question. In a democratic society, human rights appear linked to an integral conception of society; they are not only individual rights, natural rights, social rights, citizen rights, constitutional rights or individual guarantees; they are rights that express the dignity of man, of political rights, that when questioned, the form of society is questioned.

Lefort's argument (2004) rejects the idea that human rights are reduced to individual rights, since the nature of the individual is constitutive of the form of society, the rights of man define and value the type of regime. The political meaning of the rights of man is what differentiates a totalitarian regime from a democratic one, since the political nature of democratic societies gives the generating responsibility of democracy to the rights of man. The rights of man are generators of democracy, because in them legal materialization is amalgamated, which regulates the behavior of individuals and affection, the adhesion that is provoked between men. The relationship between the institutionalization of law and men's consciences is a problematic and complex relationship. It is a relationship that takes the form of a political regime.

Colligating, at one point the questioning of the Welfare State, he acquired consensus on the inefficiency of bureaucracies, the lack of fulfillment of the objectives and as a consequence his estrangement from societies. The political and administrative efficiency of the Welfare State was placed in a legal framework. The defense of individual and social rights is what provides it with institutional legitimacy (Acemoglu \& Robinson, 2012).

The perception of society integrated several different systems, whose limits, including the political and administrative system and its subsystems, are poorly valued, overlapped and sometimes diluted. The very fact that a social system includes inputs and outputs would emphasize the idea that it can be considered as an isolated unit since these processes derive in a broader analysis than they are located. This is especially true of the political system.

\section{Conclusion}

The legitimation of political and administrative processes is thought in terms of the contexts of modernity, that is, the encounter between the individual and the 
State through political representation bodies. Without a doubt, the political parties, organized as a government, are in charge of qualifying the government's own actions. In this logic, politics and the way of doing it, responds to interests, which are alien to the individual. In order to evaluate certain actions as efficient or inefficient, in the modernity project, minimum criteria or common denominators are required that allow a positive or negative evaluation of government actions. Contrary to this, in our Latin American context, the measurement parameters are adopted from different realities. To a large extent, one starts from the assumption that political integration occurs through conflict, and it is forgotten that conflict itself and consensus are the basis and end of politics.

Systems theory maintains a direct relationship with the perspectives of the new public management since it seeks to maintain a close relationship between problems and their solution. Governance in these approaches is based on the achievement of objectives, the fulfillment of results, customer satisfaction and the quantification of results.

The public administration as an institution requires reviewing its incentive, punishment, encouragement or promotion tasks to encourage society and economic agents in coordination and cooperation designs. Public administration is not only the organized activity of the State, but also the administration, conduct or directing of collective action that has its source in organized civil society. There are government efforts of increasing returns, however, society observes diminishing returns in the results since injustice, inequality, marginalization and poverty spread, the diversification of government or state policy is increasing and is no longer the main instrument of cohesion social in the strategic and institutional areas of the government.

Today, more than ever we are witnessing a redefinition of what is public and its spaces of political and administrative efficiency, the process of transition or consolidation of democracy is the backbone of the invention of our democracy. One circumstance that adds to this process is the little or no possibility that individuals have to influence this reconfiguration of the public: it seems that the public is depoliticized and becomes a private space. A self-evaluation of the government processes is presented, without the individuals necessarily participating in the design of the evaluation instruments. The depoliticization of politics, through the privatization of social processes, is fortunate in our context. The separation of power from society is manifested in that the actions, policies, programs, projects, of governments, political parties or institutions are not enough to legitimize them in a society made up of radically different individuals, who seek an integration and recognition, not only legal but social.

Today, the government as an organization acquires the form of the State: the differentiation between the political regime, the political community and the political authority is diluted in everyday events; the roles of political authority overlap with the roles of extraction and administration. When governments are effective or ineffective, they are regularly blamed on external processes, cyclical economic crises, trade disadvantages, pressures, lawsuits, or international armed 
problems. The internal problems are located in the lack of disposition or in the irresponsibility of the political parties represented in the congress to approve the state or constitutional reforms, in which the development of the country is placed. The persistence of anti-regime coalitions is the main element of legitimation or delegitimization of the government. How to combine governmental action (individual action) and integrative action (democratic) in the public administration, to find sources of political and administrative legitimacy for the State? According to Acemoglu \& Robinson (2020), the answer is found in the effect of the Red Queen, the Chained Leviathan or the cage of norms. That is in limiting the elites' control over the State and their domination over citizens, paradoxically it is necessary to increase the State's capacity, but this is being achieved by generating trust in society. The Chained Leviathan is the State with the force to fulfill property rights and contracts, but without the force to overcome them. Finally, the cage of norms suggests a crossroads between norms that emerge as an interpretation of shared justice and norms that found a despotic authority. Freedom and legitimacy can appear or disappear in the rules.

There are certain consensuses that point towards governance as a form of public action. In legislative matters, while formalism prevails, laws cannot be considered as true political decisions, rather, they will be considered as a process of pseudo-regulatory elaboration. However, it must be recognized that one of the factors that aggravate legislative formalism comes from foreign pressure, precisely because international organizations and technical and financial assistance programs are oriented towards problems of economic development and public administration, rather than to the fundamental problem of political development. International hubs often outline and promote the use of model structures to be used by developing countries.

In this way, foreign influence weakens participation without ensuring the desired practical effects. An example of what has been discussed is the administrative reform programs or plans, in which, once the technical studies have been carried out, their conclusions are translated into laws and regulations and with significant frequency, their subsequent ineffectiveness is verified. This implies that the proposed changes have only rearranged the formal structures but have not seriously affected the underlying social and power structure, which is what determines, in fact, bureaucratic action.

It is often argued that a Constitution provides the fundamental basis for effective public exercise. However, we can think of a more convincing inverse relationship, that is, that effective parliamentary activity gives validity and legitimacy to a Constitution. When a legislature is unable to make applicable decisions, public disappointment and apathy turn against the Constitution, as does the assembly itself. When the Constitution itself reflects great social expectations, its legitimation requires increasing successes, since without them the system is discredited, and popular consensus does not develop.

A democratic political regime is legitimized by the constant and peaceful renewal of political power, through an electoral process that includes the electoral 
participation of citizens; for its part, an authoritarian regime bases its credibility on the control and stability of the emerging and traditional groups of society. Public administration is an institution that does not form its legitimacy in electoral processes, that is, in participation that becomes representation or in the possibility, which is allowed, to be monitored by social and political organizations, is legitimized by a job daily communication rationality, legitimation of their actions and the public value that it generates. In a context of political alternation, public administration is part of the discourse of change, as an instrument of legitimation of the regime. Legitimation under these conditions is not derived from decisional efficiency. While in the immediate past, the public was identified with the state, today the existence of a non-state public space and different forms of coordination and agreement between the two has to be admitted. What is the particularity of these forms? How to enhance these forms? What requirements are posed to strengthen them and make them sustainable? These are some questions that will guide future studies.

It is not only recognizing the diversity of actors, but also the expansion of public space. Today, the expressions of organized civil society are varied, which go on to play a fundamental role in the functioning of our society, the rights of man are defended and a minimum threshold is demanded that allows us to be recognized as citizens of the same community, a sense of belonging is promoted, new links are presented that allow the social fabric to be expanded. The notion of the social, which was first expressed in the political sphere as a social contract, is limited by the facts that are presented, now the defense of the social demands institutions with an instituting and instituted value that indicate us from where to judge what is right and what is wrong, what is admissible and what is inadmissible, the just of the unjust in a society: common sense is what we have in common. The redefinition of deliberation approaches a social question. It will be necessary to continue revaluing political and administrative efficiency as institutions, which have an instituting value in society, the value of the institutions is granted by the members of the community when they see it necessary, otherwise the organizations impose their value in a way instituted.

\section{Conflicts of Interest}

The author declares no conflicts of interest regarding the publication of this paper.

\section{References}

Acemoglu, D., \& Robinson, J. (2012). Por qué fracasan los países. España: Deusto.

Acemoglu, D., \& Robinson, J. (2020). El pasillo estrecho. México: Crítica.

Almond, G., \& Bingham, P. (1972). Política comparada. Buenos Aires: Paidós.

Arenilla Sáez, M. (2010). Presentación. In M. Arenilla Sáez (Ed.), La administración pública entre dos siglos (pp. 19-22). Madrid: INAP.

Arenilla Sáez, M. (2011). Marco teórico actual de la administración pública. In M. Are- 
nilla Sáez (Ed.), Crisis y reforma de la administración pública (pp. 1-137). España: Netbiblo.

Baena del Alcázar, M. (2010). Manual de ciencia de la administración. Madrid: Sintesis.

Barzelay, M. (2003). La nueva gestión pública. México: FCE.

Bielsa Callau, J. (2020). Acemoglu, Daron y Robinson, James A; El pasillo estrecho, estados, sociedades y como alcanzar la libertad. Revista de economía crítica, 29, 160-162.

Blanco, I., \& Gomà, R. (2002). Proximidad y participación: Marco conceptual y presentación de experiencias. In I. Blanco, \& R. Gomà (Eds.), Gobiernos locales y redes participativas (pp. 21-42). Barcelona: Ariel.

Buchanan, J. \& Tullock, G. (1993). El cálculo del consenso. Buenos Aires: Planeta-Agostini.

Deutsch, K. (1998). Política y gobierno. México: FCE.

Easton, D. (1996). Categorías para el análisis sistémico de la política. In D. Easton (Ed.), Enfoques sobre teoría política (pp. 216-231). Buenos Aires: Amorrortu.

Easton, D. (2012), Esquema para el análisis político. Buenos Aires: Amorrortu.

Franch Parella, J. (2020). Reseña del libro, El pasillo estrecho de Daron Acemoglu y James A. Robinson, Deusto 2019. Procesos de mercado: Revista europea de economía poítica, 17, 505-516.

Günther J., \& Cancio Meliá, M. (2003). Derecho penal del enemigo. Madrid: Civitas.

Hall, P. y Taylor, R (1999). La ciencia política y los tres nuevos institucionalismos. La revista conmemorativa del colegio, 25 Aniversario (1974-1999), 15-51.

Huntington, S. (2016). El orden político en las sociedades en cambio. México: Paidós.

Kast, F., \& Rosenzweig, J. (1977). La perspectiva moderna. Un enfoque de sistemas. In G. Campero, \& J. Vidal (Eds.), Teoría general de sistemas y administración pública (pp. 225-250). Costa Rica: EDUCA.

Lefort, C. (1990). La invención democrática. Nuevos Aires: Nueva visión.

Lefort, C. (2004). La incertidumbre democrática. Ensayos sobre lo político. México: Anthropos.

Lefort, C. (2007). El arte de escribir y lo político. Barcelona: Herder.

Linz, J. (1996). La quiebra de las democracias. Madrid: Alianza.

Linz, J. (1997). Democracia presidencial o parlamentaria. In J. Linz, \& A. Valenzuela (Eds.), Las crisis del presidencialismo. 1 perspectivas comparativas (pp. 25-143). Madrid: Alianza.

Maestre, A. (1994). El poder en vilo. En favor de la política. Madrid: Tecnos.

March, J., \& Olsen, J. (1997). El redescubrimiento de las instituciones. La base organizativa de la política. México: FCE.

Mintzberg, H. (2002). La estructura de las organizaciones. Barcelona: Ariel.

Morlino, L. (1985). Como cambian los regímenes políticos. Madrid: Centro de Estudios Constitucionales.

Nolte, D. (1991). Procesos de descentralización en América Latina: Enfoque comparativo. In D. Nolte (Ed.), Descentralización política y consolidación democrática. Europa-América del Sur (pp. 73-87). Madrid: Nueva sociedad.

Nozick, R. (1990). Anarquía, Estado y utopía. México: FCE.

Peters, G. B. (2003). El nuevo institucionalismo. Teoría institucional en ciencia política. España: Gedisa. 
Powell, W. W. \& Dimaggio, P. J. (1991). Introducción. In W. W. Powell, \& P. J. Dimaggio (Eds.), El nuevo institucionalismo en el análisis organizacional (pp. 33-75). México: Colegio Nacional de Ciencias Políticas y Administración Pública-Universidad Autónoma del Estado de México-FCE.

Rustow, D. (1992). Transiciones a la democracia. Hacia un modelo dinámico. In M. Merino Huera (Ed.), Cambio político y gobernabilidad (pp. 151-178). México: CNCPyAPCONACYT.

Sorensen, G. (2011). La transformación del Estado. Más allá del mito del repliegue. México: Tirant lo blanch.

Tilly, Ch. (2010). Confianza y gobierno. Buenos Aires: Amorrortu.

Uvalle Berrones, R. (2009). Condiciones, procesos y tendencias de la administración pública contemporánea. Convergencia, 49, 73-102.

http://www.scielo.org.mx/pdf/conver/v16n49/v16n49a4.pdf

Weber, M. (2019). Economía y sociedad. México: FCE. 